\title{
OOR BOEKE.
}

C. Louis Leipoldt: Jan van Riebeeck, Founder of European Civilization in South Africa. A. Biographical Study. Longmans Green and Co., 292 blss.

Sedert die verskyning van $\mathrm{Dr}$. Theal se werke oor Suid-Afrika is ons kennis van die lewe en werk van Jan van Riebeeck, die grondlegger van die Europese beskawing in ons wêrelddeel, van verskeie kante verryk. So het in 1909 die Fransman, Dr. Henri Dehérain 'n poging aangewend om die beeld van Van Riebeeck te rekonstrueer volgens Leibbrandt se Precis of the Archives en verdienstelike werk gelewer as gelet word op die karigheid van sy bronne. In 1912 het verskyn die deeglik wetenskaplike en goedgedokumenteerde lewensbeskrywing deur Dr. Godee-Molsbergen, wat deur dieselfde skrywer verder aangevul is met 'n paar belangwekkende studies in sy gesellig en meer populêr geskrewe buek, Tydens de Oost-Indiese Compagnie, wat in 1932 verskyn het. Die werk van Dr. Leipoldt sal laasgencemde werke gewis nie vervang nie, omdat dit geen belangrike nuwe lig op die onderwerp werp nie en omdat dit deur gebrek aan behoorlike dokumentering vir die vakman en die student van minder nut is. Maar dit sal die figuur en die werk van Van Riebeeck onder die aandag van ' $n$ veel breër leserskring bring, en om hierdie rede alleen al is die verskyning van die werk seker geregverdig.

Dr. L. het veral aandag gewy aan die kultuurhistoriese toestande van die Holland waarin Van Riebeeck opgegroei het. Nie minder as drie hoofstukke word gewy aan die Hollandse agtergrond en die kinder- en jongelingsjare van Van Riebeeck nie, en dit terwyl uit hierdie tyd van sy lewe weinig van hom per- soonlik bekend is. Dr. L. het die leemte aangevul deur die kinder- en skoollewe van die deursnee Hollandse burgerkind uit te beeld en om veral met geesdrif die opleiding van 'n chirurgyn in die wondmeestersgilde, waar v. $R$. sy heelkunde bestudeer het, te skets. Dit het die voordeel, dat by afwesigheid van persoonlike gegewens, dit ten minste 'n idee gee van die invloede wat waarskynlik op die jong v. Riebeeck ingewerk het.

Hinderlik in hierdie deel sowel as deur die hele werk is die skrywer se slegbemantelde afkeer van die godsdiens en veral van die Calvinisme, waardeur hy dikwels alle historiese perspektief en ewewig verloor. So word die vooruitgang van Holland toegeskrywe alleen aan die Arminiane, wat die vaandel van die liberalisme hoog gehou het teen die bekrompe Calvinisme, "a stocism without the vision and charity of its Roman prototype." Nog skerper tree dit op die voorgrond by die behandeling van die s.g. Gebed van Van Riebeeck, 'n gebed deur die bewindhebbers opgestel vir gebruik van die amptenare, met 'n paar wysiginge om te pas by die besondere geleentheid van die ekspedisie na die Kaap. Reeds Dr. Godee-Molsbergen het gewys op die mengsel van godsdiens en kommersialisme wat hierin voorkom, iets wat nie beperk is tot die O.I.K. in die sewentiende eeu nie. $\mathrm{Na}$ aanleiding hiervan oordeel dr. L.: In course of time the tradition of this hypocrisy has become, like the legend of the innate Puritanism of the South African Dutch, so firmly fixed in the country which van Riebeeck lounded that its curse soddens the moral atmosphere of officialdom today.... The country is now, as it was in van Riebeeck's time, preponderantly non- 
Christian, and the vaunted Puritanism of its Dutch section, a relic of covenanting Scottish intolerancy, is confined to a relative small minority.

Van Riebeeck word genoem a liberal-minded individual, who accepts the traditional conception of faith not because he is convinced of its innate truth but because it was the official and conventional conception which he was in duty bound to respect.

Hiervoor word geen bewys nodig geag nie. Die neiging tot ligvaardige generalisasie en haastige gevolgtrekkinge word trouens ook in ander opsigte aangetref. In die hoofstuk oor die eerste boere word b.v. 'n baie swart skildery van ons boerderytoestande opgehang. Die ou idee dat die boer die ruggegraat van die land is in ' $n$ land waar boerdery ' $n$ onekonomiese bedryf is, word aan die kaak gestel as die bron van al die politieke, sosiale en finansiële moeilikhede wat die land teister. Hierby word skynbaar vergeet dat die grondslag van die opvatting nie bloot ekonomies is nie, maar veral die gedagte behels dat die landelike bevolking 'n onskatbare fisiese en geestelike reserwekrag vir elke land beteken, ' $n$ gedagte wat in die nuwe Duitsland b.v. so sterk op die voorgrond tree. Die landbou in Suid-Afrika kan volgens dr. L. sy inwoners nie voed sonder dat ondervoeding en liggaamlike agteruitgang volg nie; die veeteelt is in ' $n$ bejammerenswaardige toestand. Om hierdie onekonomiese bedryf aan te moedig is wetgewing daargestel wat pryse verhoog en so die agteruitgang van die bevolking verhaas.

Mens kan vrede hê met hierdie teorieë, dit aanvaar of nie, maar dit word tog darem bedenklik wanneer in 'n ernstige geskiedeniswerk al hierdie betreurenswaardige dinge gladweg toegeskrywe word as the lamentable consequences of the policy forced upon him (Van Riebeeck) by his superiors.

Dr. Leipoldt is inderdaad op sy beste in hierdie werk wanneer hy aan die hand van sy bronne die werksaamhede van Van Riebeeck en die ontwikkeling van die Kolonie onder sy leiding beskrywe. Dan skrywe hy met insig en kennis van sake wat hoë waardering verdien. Hierdie gedeeltes maak die werk waardevol.

Die karakter van Van Riebeeck het sinds die tyd toe dr. Theal daar 'n vry ongunstige beeld van geteken het, die belangstelling van navorsers geniet. In 'n paar skitterende paragrawe het dr. Godee-Molsbergen ' $n$ heel ander beeld van Van Riebeeck geteken, en in 1915 het dr. W. Blommaert in 'n reeks artikels in "De Burger" afdoende bewys gelewer dat $d r$. Theal in hierdie opsig minder juis geoordeel het as wat gewoonlik by hom die geval is Dr. Leipoldt volg in 'n goed beredeneerde epiloog op die spoor van hierdie skrywers met 'n deeglike karaktertekening van die stigter van die kolonie aan die Kaap.

A. J. H. VAN DER WALT. Potchefstroom

\section{BOEKIES OOR GODSDIENS ONDORWYS:}

Ons het van die firma $\mathrm{Wm}$. B. Eerdmans Publishing Company, Grand Rapids, Michigan, etlike boekies vir gebruik by die godsdiensonderwys op skool en katkisasie vir bespreking ontvang.

Die eerste is ' $n$ reeks van drie boe kies oor "Christian Doctrine" deur G. W. Hylkema en E. J. Tuuk. Die eerste boekie is geskryf vir kinders van sowat 11 tot 13 jaar en in standerds 4 tot 6, d.w.s. vir die laerskoolkind; die tweede en derde is bedoel vir

(Vervolg op bls. 40.) 